\title{
Adiponectin and Gut hormones in thyroid dysfunction: a new concept (PFG axis)
}

\author{
Authors: S. Ali Emami (1), M. Reza Nazem (2), Mehdi Hedayati (1)
}

1. Cellular and Molecular Endocrine Research Center, Research Institute for Endocrine Sciences, Shahid Beheshti University of Medical Sciences, Tehran, Iran.

2. Department of Clinical Biochemistry, School of Medicine, Tarbiat Modares University, Tehran, Iran.

Objectives:

\section{Methods:}

\section{Results:}

\section{Conclusions:}

Our findings show adiponectin and gut hormones are significantly affected by thyroid dysfunction. Additionally, these hormones are noticeably correlated with each other. Hence, we would like to consider a new regulatory concept, as a novel axis (Pituitary-Fat-Gut axis).

Integration between fat tissue, gastrointestinal tract, and the brain has attracted scientific interest in recent years. Thyroid hormones influence carbohydrate mechanisms via its interaction with adipocytokines and gut hormones. Adiponectin, ghrelin and obestatin play important roles in metabolism regulation. TSH receptors have been reported to be present in adipose tissue. Moreover, gut peptides signal to their functional cognate receptors on adipocytes. Nonetheless, the limited number of studies assessing the link between thyroid, gut hormones and adipokines have yielded conflicting results.

Aim: The objective of this study was to examine the associations between adiponectin, ghrelin and obestatin in patients with thyroid dysfunction. Furthermore, there might be a cross talk between them.

This study was performed on 72 subclinical hypo- and hyperthyroids, and 33 healthy euthyroid subjects. Serum concentrations of adiponectin, ghrelin, obestatin, TSH, free T3 and free T4 were measured by ELISA, ECLIA, IRMA and RIA methods.
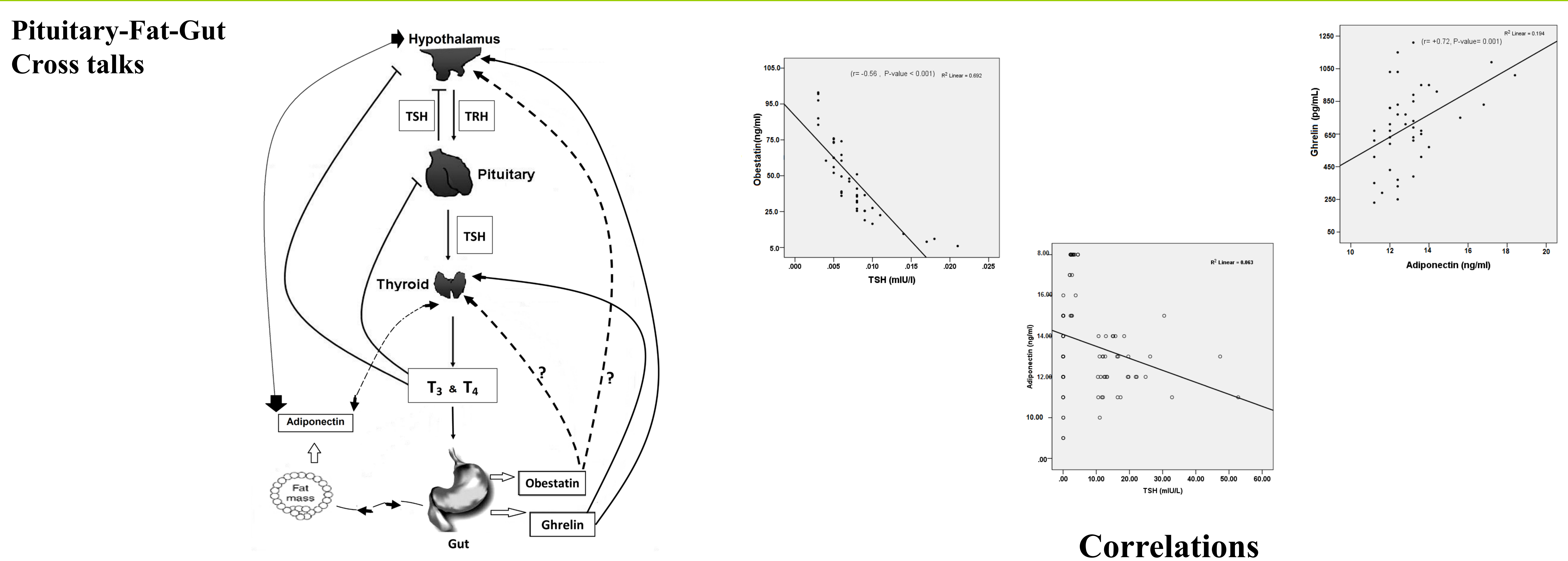

Serum levels of adiponectin were decreased in hypothyroids and increased in hyperthyroids $(11.91 \pm 5.02$ and $15.13 \pm 5.88 \mathrm{ng} / \mathrm{ml}$, respectively) than the controls $(12.73 \pm 5.19 \mathrm{ng} / \mathrm{ml}, \mathrm{p}<0.05)$. Ghrelin and obestatin values were lower in hypothyroids $(320 \pm 81 \mathrm{ng} / \mathrm{l}$ and $44.3 \pm 11.7 \mathrm{ng} / \mathrm{l}$, respectively), and higher in hyperthyroids $(750 \pm 289 \mathrm{ng} / \mathrm{l}$ and $71.1 \pm 27.3 \mathrm{ng} / \mathrm{l}$, respectively), compared to the controls $(487 \pm 110 \mathrm{ng} / 1$ and $58.5 \pm 10.3 \mathrm{ng} / \mathrm{l}$, respectively, $\mathrm{p}<0.05)$. We found a negative correlation between TSH and adiponectin $(\mathrm{r}=-0.42, \mathrm{p}<0.05)$. In addition, ghrelin and obestatin showed strong correlations with TSH $(\mathrm{r}[\mathrm{gr}]=-0.53, \mathrm{r}[\mathrm{ob}]=-0.59 ; \mathrm{p}<0.001)$. Also, strong correlations were observed between adiponetin and gut hormones $(\mathrm{r}[\mathrm{gr}]=+0.75, \mathrm{r}[\mathrm{ob}]=+0.69 ; \mathrm{p}<0.001)$.

1. Hassouna R, Zizzari P, Tolle V. The ghrelin/obestatin balance in the physiological and pathological control of growth hormone secretion, body composition and food intake. J Neuroendocrinol 2010 Jul;22(7):793-804.

2. Epelbaum J, Bedjaoui N, Dardennes R, Feng DD, Gardette R, Grouselle D, Loudes C, Simon A, Tolle V, Yang SK, Zizzari P. Role of the ghrelin/obestatin balance in the regulation of neuroendocrine circuits controlling body composition and energy homeostasis. Mol Cell Endocrinol 2010 Jan 27;314(2):244-7.

3. Kosowicz J, Baumann-Antczak A, Ruchata M, Gryczyñska M, Gurgul E, Sowiñski J. Thyroid hormones affect plasma ghrelin and obestatin levels. Horm Metab Res 2011 Feb;43(2):121-5.

4. Iglesias P, Diez JJ. Influence of thyroid dysfunction on serum concentrations of adipocytokines. Cytokine 2007 Nov;40(2):61-70

5. Zac-Varghese S, Tan T, Bloom SR. Hormonal interactions between gut and brain. Discov Med. 2010 Dec;10(55):543-52. 